\title{
FACTORS INFLUENCING STUDENTS' LISTENING COMPREHENSION AT THE FOURTH SEMESTER ENGLISH STUDY PROGRAM OF UNISI TEMBILAHAN
}

\author{
${ }^{1}$ Mukhdar, ${ }^{2}$ Melda Yeni \\ Islamic University of Indragiri

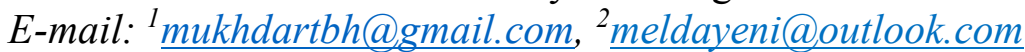

\begin{abstract}
This research was done because the researchers found that most of the students' listening comprehension of the fourth semester was low. Therefore, the researchers decided to conduct research about factors that causing it. So that the researchers want to find out students' listening comprehension factors at English study program of UNISI. This aim was achieved through a descriptive qualitative design. The sample of this research was the students of the fourth semester of English Study Program of UNISI. They consist of 13 students. They were chosen by using total sampling technique. By conducting this research, the researcher found that there are three factors influencing students' listening comprehension at the fourth semester of English Study Program of UNISI, they are reduced form, colloquial language and rate of the delivery. It can be interpreted that their low result in listening to English monologue text was because of those factors.
\end{abstract}

Key Words: Listening, Factors

\begin{abstract}
Abstrak
Penelitian ini dilakukan karena peneliti menemukan bahwa kebanyakan pemahaman listening siswa sangat rendah. Olehkarena itu, peneliti ingin meneliti tentang faktor yang mempengaruhi hal tersebut. Tujuan ini dicapai dengan penelitian descriptive qualitative. Penelitian ini mengambil sampel dari siswa semesterempat yang berjumlah 13 orang. Sampel ini diambil dengan menggunakan total sampel. Dengan melakukan penelitian ini, peneliti menemukan bahwa ada tiga faktor yang mempengaruhi kemampuan mendengar siswa, yaitu reduced form, colloquial language and rate of the delivery. Ini dapat diinterpretasikan bahwa kemampuan siswa yang rendah dalam listening dikarenakan beberapa faktor tersebut.
\end{abstract}

Kata Kunci: Mendengar, Faktor 


\section{INTRODUCTION}

Listening is one of the skills that should be mastered by the students in order to be able to use English well. English without listening will be meaningless because trough listening students can learn how to pronounce the words. Without listening to the examples of how to pronounce words well, it is impossible for the students to communicate English well. At least the students should listen to their teacher as exposure in using English.

In Indonesia, every student at each level of education should learn English as a compulsory subject. But, nowadays for elementary level, English is not as a compulsory subject anymore because of the changes in the curriculum model. However, English is still taught to them as an extracurricular. It means that English is still needed to be taught to beginners.

In university level, English is one of the important majors. This major provides students with some continuous subjects, such as speaking, listening, reading and writing. Those subjects are taught in English Journal of Indragiri (EJI) every semester. Every university has different rules for those subjects. Some universities have 3 levels of each subject above and some others have 4 levels. In UNISI, its English Study Program provides those subjects in 4 levels. Especially for listening class, it has listening 1, 2, 3 and 4. It means that this university has its own goal to make students master this skill (listening). Hence, mastering listening is not easy. It needs several efforts and strategies. Some students sometimes have their own strategies to master it, but several of them feel difficult to master it. It is because many factors influencing students listening comprehension. Many researchers had also conducted research related to this problem. According to Hamouda (2013: 118), there are various factors found by some researchers that can influence students' listening comprehension. Because of this condition, researchers also want to investigate factors influencing students' listening comprehension at the English Study Program of UNISI. 
Based on the researchers' preliminary research to the fourthsemester students of English Study Program of UNISI, they found that some students said listening is very difficult. Some others felt comprehending what the speaker means is quite hard. Besides, they also said that the speaker speaks too fast so that they can not understand what she/he means. Then, based on the information gotten from the lecturer that most of the students achieved a bad result in their examination.

Based on the description above, the researchers assumed that there are some factors influencing their listening comprehension. Therefore, the researcher had tried to find the answer of this assumption (factors influencing their listening comprehension) by conducting a research a titled: "Factors
Influencing Students'Listening Comprehension at the fourth semester of English Study Program of UNISI".

\section{METHOD}

The population of this research was the fourth-semester students of English Study Program of the Islamic University of Indragiri where the amount of them are 13 persons. Then the sample of this research was all of them. The descriptive quantitative was used as the design of this research. To collect the data, the researchers used a questionnaire with a Likert scale. All the questionnaire statements were taken from all the factors of listening comprehension indicators.

Then, the amount of the students' score will be interpreted based on the table below:

Table 1. The Students' Score

\begin{tabular}{|c|c|}
\hline Score Amount & Factor Classification \\
\hline $54-65$ & Strongly Agree \\
$43-53$ & Agree \\
$32-42$ & Undecided \\
$21-31$ & Disagree \\
$10-20$ & Strongly disagree \\
\hline
\end{tabular}




\section{FINDINGS AND DISCUSSION}

Listening is actually a hard process. The listeners cannot directly go back to the previous passage if they do not understand what the speaker means, because "listening involves real-time processing, generally without the option of going back to earlier sections of the passage the listener may have missed" (Buck, 2001; Flowerdew, 1994 in Bloomfield, et al, 2010: 3).

Besides, listening can be said as a difficult skill to be reached by the students because there are many things to be considered when they want to comprehend one spoken text. As expressed by Chengxing (2005: 1) that "listening comprehension is a complicated decoding process involves a number of basic processes, some depending upon linguistic competence, some depending upon previous knowledge, some depending upon physiological variables".

Hence, Mendelsohn (1994) in Gilakjani and Ahmadi (2011: 978) defines listening comprehension as the ability to understand the spoken language of native speakers. It means that to understand what the speaker means, students need to have special strategies, in order to understand that language spoken. Gilakjani and Ahmadi (2011: 979) also add that listening comprehension is regarded theoretically as an active process in which individuals concentrate on selected aspects of aural input, form meaning from passages, and associate what they hear with existing knowledge.

So, it can be concluded that listening comprehension is the ability of students to understand the spoken text to get information from what the speaker says. In other words, students need to be active in listening, because in listening students not only hear the passage but also try to understand it. Therefore, to understand the passage, students need to know and understand the types of listening performance. In order that they know what kinds of listening that they need in the classroom.

Based on some definitions above, it can be understood that being master on listening is not easy, it may be because of some factors 
that actually can influence students' listening comprehension. According to Brown (2000:252-254), there are eight factors influencing students' listening comprehension, they are clustering, redundancy, reduced forms, performance variables, colloquial language, the rate of the delivery, stress, rhythm and intonation and interaction. Below is a clear explanation about them:

1. Clustering is speech chunking. It happens because of the memory limitation of someone so that he or she breaks down his/her speech into smaller groups of words. Clauses are common constituents, but phrases within clauses are even more easily retained for comprehension.

2. Redundancy such as rephrasing, repetitions, elaborations and little insertions of "I mean" and "you know" help the hearer to process meaning by offering more time and extra information. Learners can train themselves to profit from such redundancy by becoming aware that not every new sentence or phrase will necessarily contain new information and the looking for the signal of redundancy.

3. Reduced forms. Reduction can be phonological (“djeetyet?" for “did you eat yet?”), morphological (contractions like "I'll"), syntactic (elliptical forms like "when will you be back?", "tomorrow may be") or pragmatic (phone rings in a house, child answers and yells to another room in the house, “mom! Phone!”).

4. Performance variable. In spoken language, except for planned discourse (speech, lectures, etc) hesitations, false starts, pauses, and corrections are common. Learners have to train themselves to listen for meaning in the midst of distracting performance variable.

5. Colloquial language such as idioms, slang, reduced forms and shared cultural knowledge are all manifested at some point in conversations. Colloquialisms appear in both monologues and dialogues.

6. The rate of delivery. Students think native speaker speaks too 
fast. Unlike reading, where a person can stop and go back to reread. In listening the hearer may not always have the opportunity to stop the speaker.

7. Stress, rhythm, and intonation. Stress can change the meaning and intonation will help listeners understand the recording, not just for interpreting straight forward elements such as questions, statements, and emphasis but also for understanding more subtle messages like sarcasm, endearment, insult, solicitation, praise, etc.

8. Interaction, to learn to listen is also to learn to respond and to continue a chain of listening and responding. Classroom technique that includes listening components must at some point include instruction in the twoway nature of listening. Good listeners are good responders. They know how to negotiate to mean (give feedback, to ask for clarification, to maintain a topic). So the process of comprehending can be complete if there is interaction.

All the factors above also become the indicators to make a questionnaire in this research.

After conducting the research, the researchers found the recapitulation of every statement that had been answered by the respondents. This is the table:

Table2. Recapitulation of Questionnaire Result

\begin{tabular}{|c|l|c|c|c|c|}
\hline No & \multicolumn{1}{|c|}{ Indicators } & $\begin{array}{c}\text { Score } \\
\text { Positive }\end{array}$ & $\begin{array}{c}\text { Score } \\
\text { Negative }\end{array}$ & Total & $\begin{array}{c}\text { Perception } \\
\text { Classification }\end{array}$ \\
\hline 1. & Clustering & 43 & 34 & $77 / 2=38.5$ & Undecided \\
\hline 2. & Redundancy & 33 & 34 & $67 / 2=33.5$ & Undecided \\
\hline 3. & Reduced forms & 46 & 42 & $88 / 2=44$ & Agree \\
\hline 4. & $\begin{array}{l}\text { Performance } \\
\text { variable }\end{array}$ & 39 & 36 & $75 / 2=37.5$ & Undecided \\
\hline 5. & $\begin{array}{l}\text { Colloquial } \\
\text { language }\end{array}$ & 51 & 45 & $96 / 2=48$ & Agree \\
\hline 6. & $\begin{array}{l}\text { The rate of the } \\
\text { delivery }\end{array}$ & 49 & 38 & $87 / 2=43.5$ & Agree \\
\hline 7. & $\begin{array}{l}\text { Stress, rhythm, } \\
\text { and intonation }\end{array}$ & 38 & 37 & $75 / 2=37.5$ & Undecided \\
\hline
\end{tabular}




\begin{tabular}{|c|l|c|c|c|c|}
\hline 8. & Interaction & 43 & 26 & $69 / 2=34.5$ & Undecided \\
\hline \multicolumn{3}{|c|}{ Total } & & $317 / 8=$ & Undecided \\
& & & 39.62 & \\
\hline
\end{tabular}

From the table of the above, it can be seen that there are three factors that influence students' listening comprehension (bold type in the table above). They are reduced form, colloquial language, and rate of the delivery. These three indicators are taken as the factors because their results are in agree category. Besides, every indicator has a different result. For clustering is 38,5. It is categorized into undecided. Then for redundancy is 33.5 , It is also categorized into undecided. The reduced form is 44 , It is categorized into agreeing. Performance variable is 37.5 , It is categorized into undecided. Colloquial language is 48 , It is categorized into agreeing. The rate of the delivery is 43.5 , It is categorized into agreeing. Stress, rhythm, and intonation is 37.5 , It is categorized into undecided. The last is interaction; it is 34.5 , where the category is also undecided. Therefore, from all the indicators, the English Journal of Indragiri (EJI) highest score is the colloquial language. Then the lowest is redundancy.

Based on the data presented above, it was found that factors influencing students' listening comprehension of the fourth semester of English Study Program of UNSI are reduced form, colloquial language and rate of the delivery. It means that students were disturbed by all these three factors. From 13 students, they agree that they were influenced by reduced form. It is a contraction form. Besides, they were also disturbed by colloquial language, where it is a kind of idiom or slang. Another factor that disturbs their listening was the rate of delivery. It is when the speaker speaks to fast, so it disturbs students' listening comprehension.

Besides, the researchers also found that the most influencing factor that disturbs students' listening comprehension is the colloquial language. Because the score for this 
indicator is 48, it is categorized in agreeing. It means that students get difficulties in understanding listening if the recording contains some slang or idioms.

\section{CONCLUSION}

This research was descriptive quantitative research. It was used to know the factors influencing students' listening comprehension of the fourth semester of English Study Program of UNISI. To answer the research question, the researcher was distributing a questionnaire to the fourth-semester students of English Study Program, especially the fourth semester. The questionnaire consists of 16 statements, 8 in negative and 8 in positive statements.

Based on the result of the questionnaire, it can be concluded that factors influencing students' listening comprehension at the English Study Program of UNISI are reduced form, colloquial language, and rate of the delivery. It can be interpreted that students' low result in listening because of those factors.

Because there are three factors influencing students' comprehension in listening (reduced form, colloquial language and rate of the delivery). So, the researchers want to give his suggestion to the following:

1. It is suggested to students in order to listen to many examples of listening materials. They can hear many examples of listening material through the internet in order that they can be familiar with idioms and slang.

2. It is also suggested for the next researchers in order to continue this research, especially about the investigation of why reduced form, colloquial language and rate of the delivery can influence students in listening comprehension.

\section{REFERENCES}

Bloomfield, Amber., at al. (2010). What makes listening difficult? Factors affecting second language listening comprehension. Maryland: University of Maryland Center for Advanced Study of Language.

Boyle, Joseph P. (1984). Factors affecting listening 
comprehension. ELT Journal:

Volume 8.

Brown, H. Douglas. (2000). Teaching by principles: an interactive approach to language pedagogy. San Francisco: Longman.

Brown, H. Doughlas, \& Abeywickrama, Priyanvada. (2010).Language Assessment; Principles and Classroom Practice. New York: Longman.

Chengxing, Li. (2005). Factors affecting listening comprehension and strategies for listening class. CELEA Journal: Volume 3.

Chao, Janet Yu-gi. (2013). Factors Affecting College EFL Learners' Listening Comprehension and Listening Problems. NCUE Journal of Humanities Vol. 8, pp. 71-84.

Gay, L.R \& Airisian, Peter. (2000). Educational Research: Competencies For Analysis And Application. London: Prentice Hall International (Uk) Ltd.

Gilakjani, Abbas Pourhossein \& Mohammad Reza Ahmadi. (2011). A Study of Factors Affecting EFL Learners' English Listening Comprehension and the Strategies for Improvement. Journal of Language
Teaching and Research, Vol. 2, No. 5, pp. 977-988. Finland: Academy Publisher.

Griffiths, Carol (Editor). (2008). Lesson from Good Language Learners. Cambridge: Cambridge University Press.

Hamouda, Arafat. (2013). An Investigation of Listening Comprehension Problems Encountered by Saudi Students in the EL Listening Classroom. International Journal of Academic Research in Progressive Education and Development April 2013, Vol. 2, No. 2

Henning, Grant. (1987). Language Testing: Development, Evaluation, Research. Massachusetts: Newbury House Publishers.

Mule, Kleopas. (2012). Types and Cause of Reading Difficulties Affecting the Reading of English Language: A Case of Grade 4 Learners in Selected Schools in Ogong Circuit of Namibia. Published Thesis. Namibia: University of Namibia.

Sugiyono. (2010). Metode Penelitian Pendidikan: Pendekatan Kuantitatif, Kualitatif, Dan $R \& D$. Bandung: Alfabeta.

Widoyoko, Eko Putro. (2014). Teknik Penyusunan Instrumen Penelitian. Yogyakarta: Pustaka Pelajar. 